AGRICULTURE AND BIOLOGY JOURNAL OF NORTH AMERICA

ISSN Print: 2151-7517, ISSN Online: 2151-7525, doi:10.5251/abjna.2013.4.4.384.387

(C) 2013, ScienceHuß, http://www.scihub.org/ABJNA

\title{
Utilization of banana peels for citric acid production by Aspergillus niger.
}

\author{
*Kareem, S.O. and Rahman R.A.
}

Department of Microbiology, University of Agriculture, P.M.B. 2240, Abeokuta, Nigeria

\begin{abstract}
The potential of Banana peels as a substrate for citric acid production by A.niger was investigated. Addition of supplements significantly enhanced the yield of citric acid. Of the three cultures examined, A.niger UABN 210 was found to produce the highest amount of citric acid $\left(82.0 \mathrm{~g} / \mathrm{Kg}\right.$ dry weight ) after $96 \mathrm{~h}$ of growth at $30^{\circ} \mathrm{C}$ in the presence of methanol $(1 \% \mathrm{v} / \mathrm{v})$ and copper ions $(10 \mathrm{ppm})$. The yield of citric acid was over $90 \%$ based on the amount of sugar consumed. The study presents banana peel as an inexpensive medium for the production of citric acid by Aspergillus niger
\end{abstract}

Keywords: Aspergillus niger, banana peel, citric acid

\section{INTRODUCTION}

Citric acid is a 6-carbon containing tricarboxylic acid which was first isolated from lemon juice. It is a natural component of many citrus fruits, and was crystallized from lemon juice by Scheele in 1784 . Approximately $70 \%$ of citric acid produced is used in the food and beverage industry for various purposes, $12 \%$ in pharmaceuticals and about $18 \%$ for other industrial uses (Yigitolu,1992) .

Commercial production of citric acid is generally by submerged fermentation of sucrose or molasses using the filamentous fungus Aspergillus niger or synthetically from acetone or glycerol (Adachi et al., 2003; Haq et al., 2004). In the recent times solid state fermentation (SSF) is considered as an alternative to submerged fermentation in the production of microbial metabolites because of higher yields, low water requirement and lower operating costs.

Many microorganisms have been evaluated for the production of citric acid including bacteria, fungi and yeast (Yigitolu,1992). However, Fungal strains of Aspergillus niger remained the organism of choice for citric acid production due to ease of handling, its ability to ferment a variety of cheap raw materials, and high yields (Schuster et al., 2002). A cost reduction in citric acid production can be achieved by using cheap agricultural wastes such as apple and grape pomace, orange peel, kiwifruit peel, cotton waste, okara soy-residue and cane molasses (Hang and Woodams,1986,1987, Yigitolu,1992, Khare et al.,1995, Haq et al.,2004,Kareem et al.,2010).

Banana waste is currently posing disposal problem in the tropics. The objective of this study was to adopt the use of banana peel for the production of citric acid by Aspergillus niger.

\section{MATERIALS AND METHODS}

Pre-treatment of Banana peels: Banana peels were collected from Industrial park of University of Agriculture, Abeokuta Nigeria and oven-dried at $60^{\circ} \mathrm{C}$ for $2 \mathrm{~h}$ and cut into $2 \mathrm{~mm}$ mesh size.

Production of Citric acid: The basal medium was prepared by introducing banana peels $(30 \mathrm{~g})$ into $200 \mathrm{~mL}$ Erlenmeyer flasks. The medium was supplemented with nitrogen supplements was studied by adding and ammonium phosphate, potassium hydrogen phosphate and peptone $(0.5 \%)$ to the basal medium. and moistened to $60 \%$ moisture content. Effect of trace elements was also studied by adding copper, iron ,manganese and zinc ions(10ppm) The flask was cotton plugged and autoclaved at $121^{\circ} \mathrm{C}$ fo r 15minutes. After cooling at room temperature, each medium was inoculated with the Aspergillus niger $\left(6.0 \times 10^{6}\right)$ suspension and incubated at $30^{\circ} \mathrm{C}$ in a rotary shaking incubator for 5 days. Methanol (0-3\%) was added to the flasks before fermentation. After fermentation, the medium was diluted with distilled water $(1: 4 \mathrm{w} / \mathrm{v})$. The medium was then filtered and the filtrate was used for the subsequent analyses.

Citric Acid determination: Citric acid was determined titrimetrically (AOAC, 1995) by using 0.1 $\mathrm{NaOH}$ and phenolphthalein as indicator and calculated as \% according to the formula:

Normality $X$ volume of $0.1 \mathrm{MNaOH} X$ equivalent weight of citric acid_X dilution factor $\%$ citric acid $=\quad$ Weight of sample $(\mathrm{g}) \times 10$

Biomass, residual sugars and $\mathrm{pH}$ determination Biomass, sugar and $\mathrm{pH}$ values were determined according to AOAC (1995). To determine biomass 
the whole fungal culture was filtered with sterile filter paper and dried to a constant weight at $105^{\circ} \mathrm{C}$. Results were expressed in $\mathrm{g} / \mathrm{kg}$ of banana peel. The sugar content was determined using a refractometer and $\mathrm{pH}$ was measured by Analog $\mathrm{pH}$ meter. Each analysis was conducted in triplicate.

\section{RESULTS}

Table 1. Effect of nitrogen supplements on citric acid production by A.niger UABN210 after $72 \mathrm{~h}$ of growth at $30^{\circ} \mathrm{C}$

\begin{tabular}{|l|l|l|}
\hline Supplements & Citric acid $\mathbf{g} / \mathbf{K g}$ dry matter & Biomass \\
\hline $\mathrm{KH}_{2} \mathrm{PO}_{4}$ & 30.81 & 12.0 \\
\hline$\left(\mathrm{NH}_{4}\right)_{3} \mathrm{PO}_{4}$ & 42.32 & 12.0 \\
\hline Peptone & 50.12 & 14.2 \\
\hline Control & 15.84 & 6.4 \\
\hline
\end{tabular}

Data are means of triplicate determinations, $\mathrm{SD}= \pm 0.5$

Table 2. Effect of methanol on citric acid production by three strains of A.niger after $72 \mathrm{~h}$ of growth at $30^{\circ} \mathrm{C}$

\begin{tabular}{|l|c|c|c|}
\hline \multirow{2}{*}{ Methanol conc.(\%v/w) } & \multicolumn{3}{|c|}{ Citric acid yield g/Kg dry matter } \\
\cline { 2 - 4 } & UABN210 & UABN97 & UABN41 \\
\hline 0 & 50.12 & 32.0 & 10.2 \\
\hline 1 & 64.20 & 43.0 & 6.6 \\
\hline 2 & 58.01 & 19.2 & 4.8 \\
\hline 3 & 46.01 & 18 & \\
\hline
\end{tabular}

Data are means of triplicate determinations, $\mathrm{SD}= \pm 0.5$

Table 3. Effect of Trace Elements on Citric acid production

\begin{tabular}{|l|l|l|l|}
\hline \multirow{2}{*}{ Trace elements } & Citric acid yield g/Kg & UABN41 \\
\cline { 2 - 4 } & UABN210 & UABN97 & 22.13 \\
\hline Cu2+ & 82.12 & 58.2 & 18.22 \\
\hline Fe2+ & 52.14 & 62.4 & 25.22 \\
\hline Mn2+ & 45.21 & 36.2 & 15.20 \\
\hline Zn2+ & 74.51 & 49.8 & 10.2 \\
\hline Control & 64.20 & 43.0 & \\
\hline
\end{tabular}

Data are means of triplicate determinations, $\mathrm{SD}= \pm 0.5$ 
Agric. Biol. J. N. Am., 2011, 4(4): 384-387

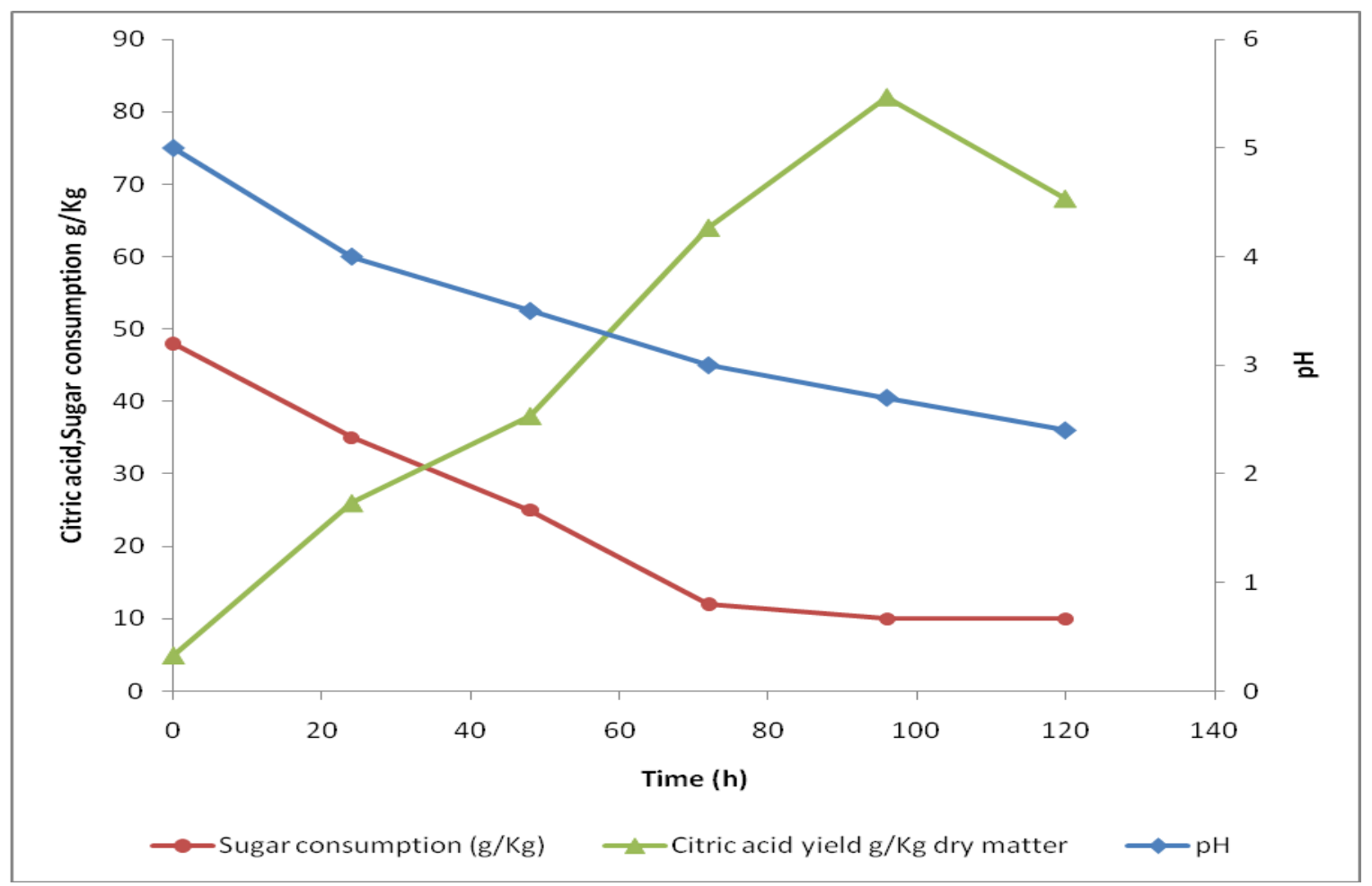

Fig 1. Time course of citric acid production by A.niger 210 from banana peel with $1 \%$ methanol at $30^{\circ} \mathrm{C}$

\section{RESULTS AND DISCUSSION}

Table 1 presents production of citric acid by A.niger on banana waste with or without supplements. A minimum citric acid production $(15.48 \mathrm{~g} / \mathrm{kg})$ was obtained in banana waste while supplementation with nitrogen sources led to an increase in citric acid secretion. Among the supplements, peptone gave a maximum citric acid yield $(30.8 \mathrm{~g} / \mathrm{kg})$ followed by ammonium phosphate $(42.32 \mathrm{~g} / \mathrm{kg})$. Nitrogen had been reported to be an important factor in fermentation processes due to an increase in $\mathrm{C} / \mathrm{N}$ ratio (Kareem et al.,2009). Nitrogen constituent has a profound effect on citric acid production because nitrogen is not only important for metabolic rates in the cells but it is also basic part of cell proteins. This report agreed with Kareem et al., (2010) that fermentation media for citric acid biosynthesis should consist of substrates necessary for the growth of microorganism primarily the carbon, nitrogen and phosphorus sources.

Effect of methanol on citric acid production was shown in Table 2. Among the three strains of A.niger. Maximum citric acid production $(64.20 \mathrm{~g} / \mathrm{kg}$ ) was exhibited by A.niger UABN 210 at $1 \%$ methanol concentration. This observation agreed with Kareem et al.(2010) that the addition of methanol to pineapple waste medium led to an increase in citric acid production by Aspergillus niger. The inductive effect of methanol for citric acid production may be due to reduction of the inhibitory effects of metal ions (Kiet et al.,1981). El-Holi M.A.and Al-Delamy K.S.(2003) found that addition of lower alcohols, methanol, ethanol, n-propanol, to crude carbohydrate raw materials could increase the yield of citric acid. Optimal concentration of methanol, which was said to be more effective than ethanol, varied from 1 to $4 \%$ by volume. However addition of methanol to highly purified, high yielding substrates is deleterious to acid yields. Hang and Woodams (1986) observed that the presence of methanol at a concentration of $3 \%$ in grape pomace led to an increase in the citrate yield . The exact mechanism of the alcohol effect however is unexplained, though it is postulated that addition of methanol increases the tolerance of fungi to $\mathrm{Fe} 2+$, $\mathrm{Zn} 2+$ and $\mathrm{Mn} 2+$.

Effect of trace elements on citric acid production as presented in Table 3 showed that copper and zinc favored citric acid production while iron and manganese exhibited deleterious effect on bioaccumulation of citric acid. Trace element nutrition is one of the most important factors affecting the yields of citric acid fermentation (Yigitolu 1992). 
Effects of fermentation period on citric acid production, $\mathrm{pH}$ and sugar consumption are presented in Figure 1. A steady increase in citric acid production was observed along the fermentation period with optimum yield $(82.2 \mathrm{~g} / \mathrm{kg})$ after fermentation for $96 \mathrm{~h}$ while a decrease in the consumption of sugar was observed. Previous reports have shown that the production of citric acid on pineapple waste approximately paralleled the consumption of sugar (Kareem et al., 2010). Based on the amount of fermentable sugar consumed, the yield of citric acid was $90.62 \%$ under optimum solid-state fermentation conditions. A decrease in $\mathrm{pH}$ values from 5.0 to 2.8 was noted after $96 \mathrm{~h}$ of fermentation (Table 3 ). The $\mathrm{pH}$ value maintained at the beginning of fermentation was important for a specific biomass formation. The progressive decrease in $\mathrm{pH}$ was noted as incubation time increased which was due to the formation and accumulation of citric acid.

\section{CONCLUSION}

This study has presented banana peels as potential materials for the production of citric acid and its utilization will facilitate large-scale production of this commercially valuable organic acids.

\section{REFERENCES}

\footnotetext{
AOAC(1995):Official Methods of Analysis, $16^{\text {th }}$ ed.Association of Official Analytical Chemist, Washington D.C.

Adachi,D.M., Toyama,H., Yamada,M., Shingawa,E.and Matsushita K.(2003):New developments in oxidative fermentation. Applied Microbiology and Biotechnology,60:643-653

El-Holi M.A.and Al-Delamy K.S.(2003): Citric acid production from whey with sugars and additives by Aspergillus niger. African Journal of Biotechnology 2(10):356-359
}

Grewal,H.S. and Kalra ,K.L.(1995): Fungal production of Citric acid. Biotechnology Advances 13:209-234

Hang,Y.D. and Woodams E.E.(1986):Utilization of grape pomace for citric acid production by Solid state fermentation. American Journal for Enology and Viticulture 37(2):141-142

Hang,Y.D. and Woodams E.E.(1987):Microbial production of citric acid by Solid-state fermentation of Kiwifruit peel. Journal of Food Science 52:226-227

Hossain M, Brooks J.D. and Moddax ,I.S.(1984):The effect of the sugar source on citric acid production by Aspergillus niger. Appl. Microbiol.Biotechnol.19:393397

Haq,I., Ali,S.,Qadeer,M.A.and Iqbal,J.(2004):Citric acid production by mutants of Aspergillus niger from cane molasses. Bioresource Technology 93(2):125-130

Kareem,S.O., Akpan,I. and Oduntan S. B.(2009) Cowpea waste- A novel substrate for the solid state production of amylase by Aspergillus oryzae. African Journal of Microbiology Research 3(12):974-977

Kareem,S.O.,Akpan,I., and Alebiowu,O.O.(2010): Production of citric acid by Aspergillus niger using pineapple waste. Malaysian Journal of Microbiology 6(2)161-165

Khare S.K., Krishna J.and Gandhi A.P.(1995): Citric acid production from okara (soy-residue) by solid-state fermentation. Bioresource Technology 54: 323-325

Maddox,I.S. and Brooks,J.D.(1998): Application of a multilayer packed bed reactor to citric acid production in solid-state fermentation using Aspergillus niger. Process Biochem.,33(2):117-123

Schuster,E., Dunn-Coleman, N., Frisvad, J.C. and Van Dijek,P.W.(2002):On the safety of Aspergillus niger -A review, Appl. Microbiol.\&Biotechnol.,59(4-5):426-435

Xu D.P., Madrid C.P., Rohr M.,and Kubicek C.P.(1989): The influence of type and concentration of carbon source on production of citric acid by Aspergillus niger.Appl. 